TRENDS IN HYDROZOAN BIOLOGY - IV. C.E. MILLS, F. BOERO, A. MIGOTTO and J.M. GILI (eds.)

\title{
Non-indigenous hydromedusae in California's upper San Francisco Estuary: life cycles, distribution, and potential environmental impacts*
}

\author{
JOHN T. REES ${ }^{1,2}$ and LISA-ANN GERSHWIN ${ }^{3}$ \\ ${ }^{1}$ Bay/Delta Shore Institute, California State University, Hayward, Building 7; 751 West Midway, Alameda Point, CA 94501 \\ ${ }^{2}$ Department of Biological Sciences, California State University, Hayward, CA 94542 U.S.A. E-mail: Johntrees@aol.com \\ ${ }^{3}$ Department of Integrative Biology, U.C. Museum of Paleontology, University of California, Berkeley, CA 94720 U.S.A.
}

\begin{abstract}
SUMMARY: Two species of hydromedusae, assumed to be native to the Black and Caspian Seas, were routinely collected in Suisun Slough, California, at the Suisun City Marina, during late summer and fall of 1997. Suisun Slough connects directly with Suisun Bay, part of the biologically complex and commercially important upper San Francisco Estuary, and with San Francisco Bay via San Pablo Bay. Maeotias marginata (Modeer 1791), has been previously reported (as M. inexspectata) from the Petaluma River, another tributary entering San Pablo Bay, while an as-yet undetermined species of Moerisia represents a new distributional record for this genus in the eastern Pacific. Morphologies of the adults and immature growth stages of medusae of both species are described. The polyp stages of both species were reared in the laboratory following spawning of adult medusae collected from the field. Both species are apparently representative of the robust and aggressive Black and Caspian Seas brackish water fauna, many species of which have been introduced into estuarine habitats worldwide. The potential of these planktonic predators to alter zooplankton communities and feed directly on larval and juvenile stages of threatened native and commercially valuable estuary fish species are all possible, but remain uninvestigated.
\end{abstract}

Key words: Maeotias marginata, Maeotias inexspectata, Moerisia sp., Moerisia lyonsi, Olindiidae, Limnomedusae, San Francisco Bay, Cnidaria

\section{INTRODUCTION}

Maeotias marginata (Modeer, 1791) (see Mills and Rees, 2000) and Moerisia sp. are the first hydromedusae to be reported from Suisun Bay, an oligohaline, usually very low salinity portion of the San Francisco Estuary situated between San Pablo Bay and the Sacramento-San Juaquin River delta. Both species were collected in Suisun Slough, a sinuous arm of Suisun Bay, during September and

*Received January 14, 1999. Accepted January 17, 2000.
October of 1997 and again in 1998. These two species are exotic introductions, and both are presumed members of the relict brackish-water Sarmatic fauna native to the Black and Caspian Seas. Both of these hydrozoans have complex life cycles consisting of asexual sessile polyps and sexual pelagic medusae. Polyps of both species were obtained in the laboratory following spawning of adult fieldcollected medusae. On the west coast of North America, Maeotias marginata (as M. inexspectata) has been previously reported in the San Francisco Estuary from the Petaluma River, which empties 
into San Pablo Bay (Mills and Sommer, 1995), while Moerisia sp. represents the first record of this genus from the Eastern Pacific.

The introduction of these medusae into Suisun Bay is significant, as no hydromedusae are known to be native to this bay. Jellyfish are important, though little-appreciated and understudied, secondary consumers on the zooplankton and zoobenthos in many other habitats. Under certain environmental conditions, hydromedusae can attain very high local abundances (blooms) and under such circumstances are capable of severely depleting and altering the structure of local zooplankton communities. Some hydromedusae are also known to feed directly on commercially valuable larval and juvenile fish. Here we document the life history stages of two introduced species and report initial results of field work which aims to investigate the capabilities of these hydrozoans to invade and impact sensitive estuarine environments. Knowledge of the basic biology of these cnidarians, as well as other aggressive invaders of estuarine habitats, is needed if appropriate preventative measures are to be instituted towards limiting negative impacts of alien introductions in vulnerable and economically important estuarine habitats around the world.

\section{MATERIALS AND METHODS}

On information that unidentified jellyfish had been observed in Suisun Bay, one of us (L.G.) undertook a field excursion to the marina adjacent to downtown Suisun City, located at the end of Suisun Slough, in early September 1997. At that time adult jellyfish, subsequently identified as Maeotias marginata, were seen in abundance at the water surface. Through routine plankton tows taken alongside the marina dock, a second hydromedusan species, later identified as Moerisia sp., was found to be sporadically abundant at the marina. Growth stages of both medusae were collected, photographed, and preserved.

\section{Field Collections}

Medusae of M. marginata and Moerisia sp. were collected weekly at the Suisun City Marina from midSeptember to October 29, 1997, by taking horizontal plankton tows with a $0.25 \mathrm{~m}$ diameter, $500 \mu \mathrm{m}$-mesh net at about $0.5 \mathrm{~m}$ depth over a 1-2 meter bottom. A secchi disc was used to determine water clarity.
Large $M$. marginata were only occasionally collected in this manner, although immature stages of the medusa were routinely dip-netted from the surface where they were visible. A complete series of growth stages of M. marginata and Moerisia sp. were collected during the study period. Living medusae were further observed and photographed in the laboratory. Adult Moerisia sp. medusae were fed Artemia nauplii; M. marginata medusae ate bits of minced, cooked shrimp.

A cursory search in the field for the polyps of both species was made on local docks and other substrates, including scrapings from pilings and sides and bottoms of floating docks. None were found, although the polyps of both species were subsequently reared from mature medusae spawned in the laboratory. Initially, all M. marginata medusae collected were males, as previously reported by Mills and Sommer (1995) from the Petaluma River. In early September 1998, a few female M. marginata medusae were collected in the Napa River (which empties into San Pablo Bay), and primary polyps were obtained by spawning adult male and female medusae in the laboratory.

\section{Laboratory Culture}

Adult medusae were taken to the laboratory, sorted by sex using a dissecting microscope, and placed in $10 \mathrm{~cm}$ diameter glass rearing bowls filled with water collected from Suisun Slough. Laboratory culture techniques followed those described by J.T. Rees (1979) for Eutonina indicans. Release of eggs was observed, and development and subsequent settlement of planulae took place directly on the bottoms of the bowls. Primary and adult polyps thrived on newly hatched Artemia nauplii. Newlyreleased medusae obtained from polyps were transferred to small ( $5 \mathrm{~cm}$ diameter) plastic culture containers and reared to maturity. All cultures were fed once daily. Culture water was changed every second day prior to feeding. Culture temperature ranged from $18-21^{\circ} \mathrm{C}$; salinity was maintained at about 10 psu (practical salinity units). No aeration was used in polyp or medusa culture containers. Salinities were measured in both the field and laboratory with a hand-held refractometer or a specific gravity meter calibrated with a refractometer. Nematocysts of both species were examined using a compound microscope at 500 and $1000 \mathrm{X}$ in squash preparations; measurements given are for unexploded nematocysts. 
Photographic documentation of the life history stages of Maeotias marginata and Moerisia sp. from Suisun Slough is presented in Figures 1-6 and nematocysts are shown in Figure 7. Salinites and temperatures at the field site ranged from 7-10 psu, and $18-19^{\circ} \mathrm{C}$, respectively, throughout the study period. Turbidity at the site was high and secchi disc readings were always $25 \mathrm{~cm}$ or less.
M. marginata medusae were collected in the field in 1997 and 1998 between late August and early November. Despite numerous plankton tows, almost all medusae captured were adults $25 \mathrm{~mm}$ in diameter or greater, indicating that the peak period of release of the medusa from the hydroid had been earlier in the year. A few very small M. marginata medusae were collected in October, indicating that
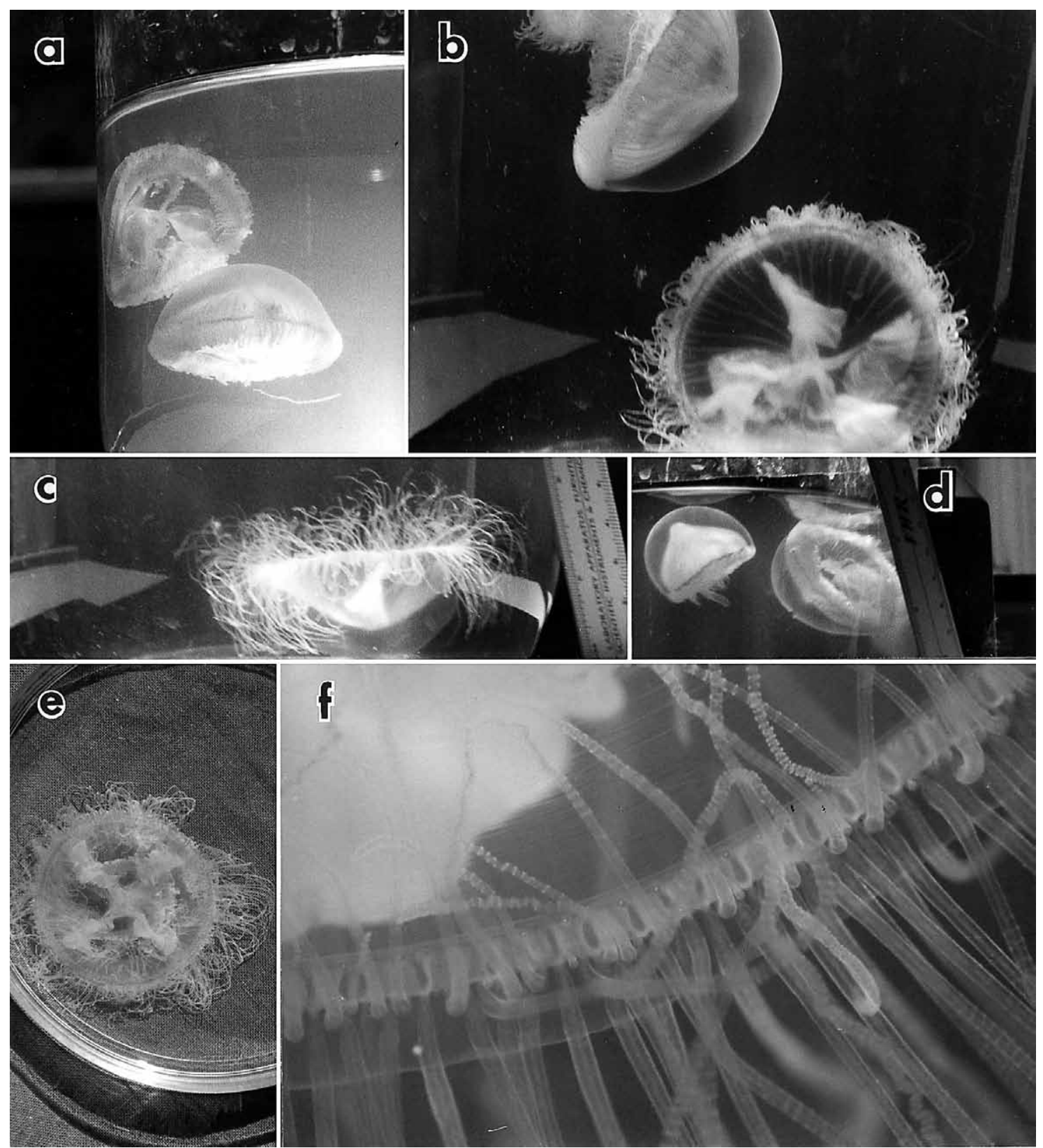

FIG. 1. - Maeotias marginata, adult medusae, $3.0-5.0 \mathrm{~cm}$ in bell diameter. (a,b) Lateral and oral views: note thickness of the mesoglea, conical subumbrellar profile, curtain-like gonads, centripetal canals, and numerous tentacles. (c) Lateral view of typical resting posture of medusa on the bottom. (d) Medusa at left shows maximum contraction of the bell while swimming. (e) Oral view of typical resting position on bottom. (f) Magnification of bell rim showing tentacles with rings of nematocysts, oval-shaped pigmented areas at bases of tentacles, and statocysts between the tentacle bases. 
occasional medusae were still being released from the hydroid at this time. The biggest adults were 50 $\mathrm{mm}$ in bell diameter, among the largest reported for this species, including those collected and described from native habitat in the Sea of Azov and other areas in the Black Sea (Kramp, 1961; Mills and Sommer, 1995). Size class measurements taken in late September and October showed that the medusae were still increasing in mean size in October. According to local marina boat owners, smaller "dime-sized" ( $\sim 15 \mathrm{~mm}$ bell diameter) medusae had been present and visible in great numbers at the surface in late July. These medusae were apparently juvenile $M$. marginata, with mature adults having $4-5 \mathrm{~cm}$ bell diameters still present and abundant in mid-September.

The time of introduction of M. marginata into Suisun Slough is unknown, but a preliminary review of field notes from California Fish and Game and U.S. Fish and Wildlife Service collections in the nearby Sacramento-San Juaquin River delta (upper San Francisco Bay Estuary) indicates that this species may have been present (and intermittently collected) there since 1959. Location of preserved specimens would be necessary to verify the species identification of these early records.

\section{Morphology and Growth Stages of the Medusa (Figs. 1-3)}

The morphology of the adult medusa is shown in Figure 1. Adult medusae were observed in various behavioral postures, including resting in a presumed feeding posture on the bottom, exumbrella downward, with tentacles outstretched (Fig. 1c, e). Live adult medusae at rest were wider than high, and in the field were generally an all-over light-brownish, or occasionally reddish, color. The mesoglea of the bell was clear in younger specimens, becoming more opaque as the medusae mature.

Gonads hung down from each of the four radial canals in folded sheets (Fig. 1b,e). The rim of the bell appeared as a characteristically brownish or reddish ring due to discrete areas of pigmentation at the bases of the tentacles. Alternating cycles of centripetal canals, each beginning at the ring canal and extending towards, but not actually reaching, the stomach, were visible between the four radial canals (Fig. 1b).

Mature medusae ( $\sim 30-50 \mathrm{~mm}$ bell diameter) had about 450-600 tentacles; the tentacles had prominent and characteristic rings of nematocysts. Stato- cysts, each with a single inclusion, were located alongside the ring canal. No sensory clubs were present among the tentacles, confirming the observations of Mills and Sommer (1995). The large size, with bell wider than high, large number of tentacles, presence of very long centripetal canals, and a brownish or reddish bell rim render adult medusae of $M$. marginata distinctive.

Selected growth stages of the medusa are shown in Figures 2 and 3. The smallest medusa collected from the plankton (Fig. 3c,d,e) was $0.7 \mathrm{~mm}$ in bell height and $0.9 \mathrm{~mm}$ in bell diameter, and, since most new hydrozoan medusae are about $1.0 \mathrm{~mm}$ or less in bell height and grow rapidly, had probably just been released from the hydroid. The stomach had a characteristic quadrate base (Fig. 3d) and about 24 tentacles, each terminating in a club-shaped battery of nematocysts (Fig. 3e), all microbasic euryteles, surrounded the rim of the bell. Each tentacle appeared to have a solid endodermal core. There were four interradial marginal vesicles around the bell margin. Even at this very young stage, pigment granules were discernible around the bell margin (Fig. 3e); no centripetal canals were present.

In somewhat larger specimens $(\sim 1.5 \mathrm{~mm}$ bell height, $2.5 \mathrm{~mm}$ bell diameter) the marginal vesicles (now 3 per quadrant, each with a single statocyst), and broad radial and ring canals, all typical of larger medusae, were clearly visible (Fig. 2b). The manubrium hung down about $1 / 3$ of the subumbrellar cavity length and there were about 50 tentacles. Four lips, precursors of the four elaborately-frilly manubrial lobes of adults, had begun to develop. The centripetal canals characteristic of adults were not yet present.

Medusae of 4-5 $\mathrm{mm}$ in bell height had about 200-250 tentacles, with the first signs of centripetal canals emanating from the ring canal. Gonads were beginning to develop on the radial canals near the manubrium.

In medusae $10 \mathrm{~mm}$ in bell diameter (Fig. 2c,d), developing gonads were clearly evident along the proximal half of the radial canals, and the four lips of the manubrium had begun to exhibit their characteristic frills. Centripetal canals were present in medusae of this size, although the animals were not yet sexually mature. The tentacle number was approaching 400. The broad ring canal, marginal vesicles with single statocysts, and numerous tentacles with prominent nematocyst rings enable this growth stage to be easily identifiable as $M$. marginata. 

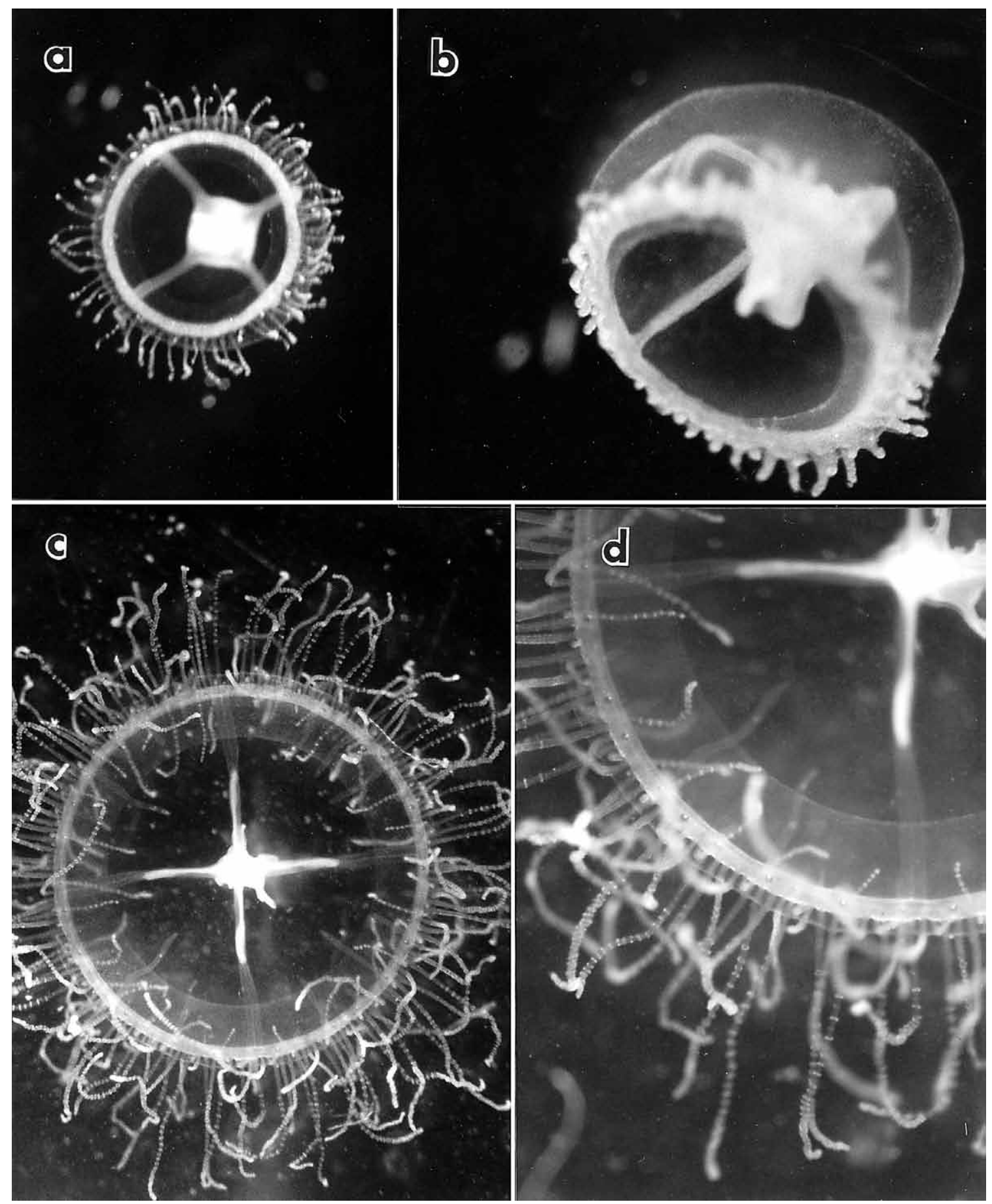

FIG. 2. - Maeotias marginata, growth stages of the medusa. (a) Very young medusa $1.0 \mathrm{~mm}$ in bell height and $1.5 \mathrm{~mm}$ bell diameter, showing numerous tentacles, broad radial and ring canals, and quadrate stomach. (b) Oblique view of young medusa about $1.5 \mathrm{~mm}$ bell height and $2.5 \mathrm{~mm}$ bell diameter: note beginning of formation of lips on the manubrium. (c,d) Two views of the same medusa, about $10 \mathrm{~mm}$ in bell diameter: note broad ring canal and marginal statocysts, numerous tentacles with prominent nematocyst rings, manubrium with frilled lips, and beginnings of gonad development along the radial canals.

The polyp (Fig. 3a,b)

The polyp described and figured as M. marginata (=inexspectata) by Mills and Sommer (1995) is undoubtedly that of Moerisia sp. (see below). In
September 1998, one of us (J.T.R.) obtained primary polyps of $M$. marginata (Fig. 3a,b) by laboratoryspawning field-collected adult medusae. Eggs were small ( $\sim 50 \mu \mathrm{m}$ diameter) and settled immediately to the bottom of culture bowls after release. Swimming 

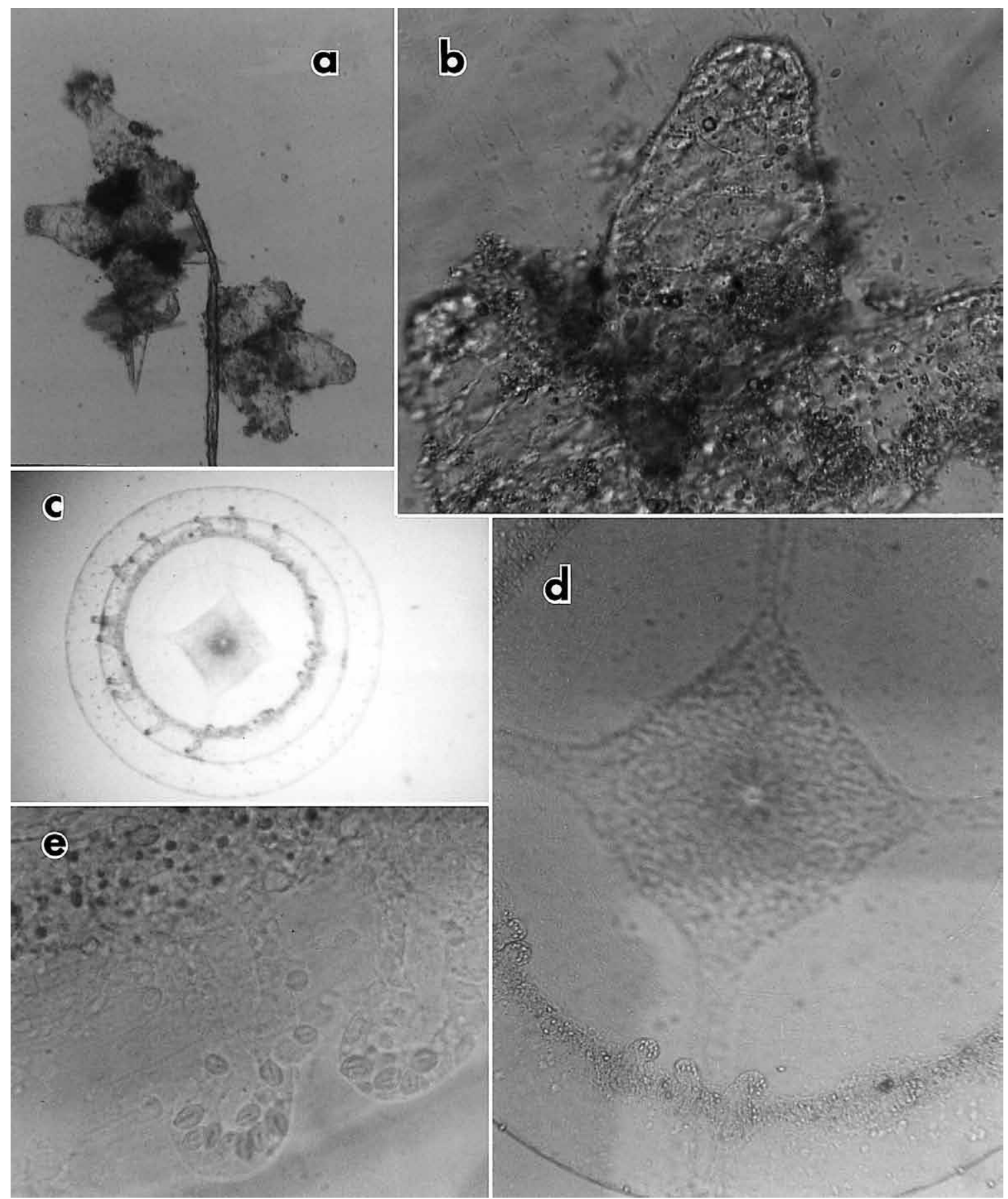

FIG. 3. - Maeotias marginata, primary polyp and very young medusa. (a) Group of primary polyps in the laboratory, each developed from a separate fertilized egg: each polyp is about $0.1 \mathrm{~mm}$ in height. (b) Enlargement of group of primary polyps: note nematocysts at the apex of the center polyp and large, clear cells of the polyp body. (c) Very young medusa, about $0.7 \mathrm{~mm}$ bell ht, $0.9 \mathrm{~mm}$ bell diameter with 24 tiny tentacles. (d) Enlargement of (c): note quadrate stomach and broad radial and ring canals. (e) Enlargement of tentacles: note microbasic eurytele nematocysts in the terminal tentacle knobs, solid endodermal core of tentacles, and pigment granules in the ring canal.

planulae did not develop, but polyps developed directly from eggs, on bits of loose detritus, which appeared to stick to the eggs and the bases of developing polyps, rather than on the glass of the finger bowls. Primary polyps were minute $(\sim 0.1 \mathrm{~mm}$ in height), inconspicuous, atentaculate, and similar in gross morphology to those few olindiid primary and adult polyps which are known, such as Aglauropsis aeora (Mills et al., 1976) and Craspedacusta sowerbii (see Russell, 1953). The body of the hydranth was composed of large, transparent cells. Nematocysts of primary polyps, which appeared to be all 
microbasic euryteles, were oriented around what was presumed to be a mouth (Fig. 3b), although despite repeated attempts, polyps were never seen to feed, and no mouth or polyp gastric cavity was discernible. The entire behavioral repertoire of these tiny polyps consisted of slow and modest extensions and contractions of the polyp body. Efforts to rear the polyps were unsuccessful and whether further morphological change occurs is unknown.

\section{Cnidom}

All nematocysts in the medusa, on both the tentacles and the lips of the manubrium, were of one kind only, microbasic euryteles (Fig. 7a,b). In adult medusae of $40 \mathrm{~mm}$ bell diameter, these microbasic euryteles were of 2 sizes, with the larger size, 11-16 x 8-10 $\mu \mathrm{m}$ located on the tentacles, and the smaller size, 9-11 x 6-7 $\mu \mathrm{m}$ on the manubrium lips. Primary polyps also had a monocnidom of microbasic euryteles, but none were measured. Similarlyshaped euryteles have been reported in other olindiid limnomedusae such as Aglauropsis aeora, A. conanti, and Eperetmus typus (Mills et al., 1976).

\section{Behavior}

The adult Maeotias marginata medusa is a powerful swimmer, able to propel itself through the water several centimeters with each pulsation of the bell. In the field, medusae were routinely observed pulsing vertically to the surface, then flipping over and slowly sinking without pulsing, exumbrelladownward and tentacles extended. It is thought that $M$. marginata medusae spend the majority of their time on the bottom, so that medusae observed on the surface represent only a small portion of the total population present (Mills and Sommer, 1995). The medusae could not be observed on the bottom due to the turbidity of the water at the study site. When at rest on the bottom, the subumbrella and outstretched tentacles (Fig. 1c,e) are presumably used as a capture surface to snare food falling from the overlying water column. Prey are undoubtedly also captured as the medusae sink through the water column on their way to the bottom. Such a behavioral repertoire may be unique to some members of the family Olindiidae; it is also characteristic of Gonionemus vertens, whose species name recognizes the medusa's flipping over upon hitting the surface (Agassiz, 1862; C.E. Mills, personal communication)
In the laboratory, adult medusae spent most of their time resting on the bottom, with the oral opening oriented towards the surface (Fig. 1c,e). Resting medusae in the laboratory were fed by placing small bits of cooked shrimp or fish directly on the exposed subumbrella or tentacles. Adult medusae were maintained for 2-3 weeks in the laboratory, but did not thrive. Feeding habits of the smallest medusae are unknown. Although they presumably feed by capturing plankton with their tentacles and transferring the prey to the mouth in typical hydromedusan fashion, we were unable to keep the smallest medusae alive in the laboratory.

\section{Systematics}

Due to the presence of a monocnidom of microbasic euryteles and the presence of statocysts in immature and adult medusae, $M$. marginata should be retained in the order Limnomedusae, family Olindiidae. Confirmation of the ultimate taxonomic status of $M$. marginata must await detailed laboratory culture work on the entire life cycle, including the structure of the adult polyp and newlyreleased medusa. Molecular analyses and comparisons with other Anthomedusae and Limnomedusae should also aid in the systematic placement of this species as well as the entire family Olindiidae.

\section{Moerisia sp.}

We found Moerisia sp. medusae within the same time frame and in the same location as M. margina$t a$, although the presence of this species was more sporadic (and it was rarely seen by naked eye). Moerisia sp. medusae of all ages were occasionally collected in 5-minute plankton tows, but then not collected in replicate tows taken immediately afterwards. Presence of medusae did not seem to correlate with time of day. To determine if medusae were exhibiting a diurnal migration, a 24-hour series of surface plankton tows was taken at selected locations at the Suisun City Marina. Few Moerisia sp. were collected in total, and no correlation with time of day or night was evident. We now believe that these medusae are transported into the marina area on rising tides, a hypothesis which will require further sampling for verification.

Due to the apparent necessity for taxonomic revision of the family Moerisiidae, we were unable to assign a species name to the Moerisia from Suisun Slough. While a medusa very similar to ours has 


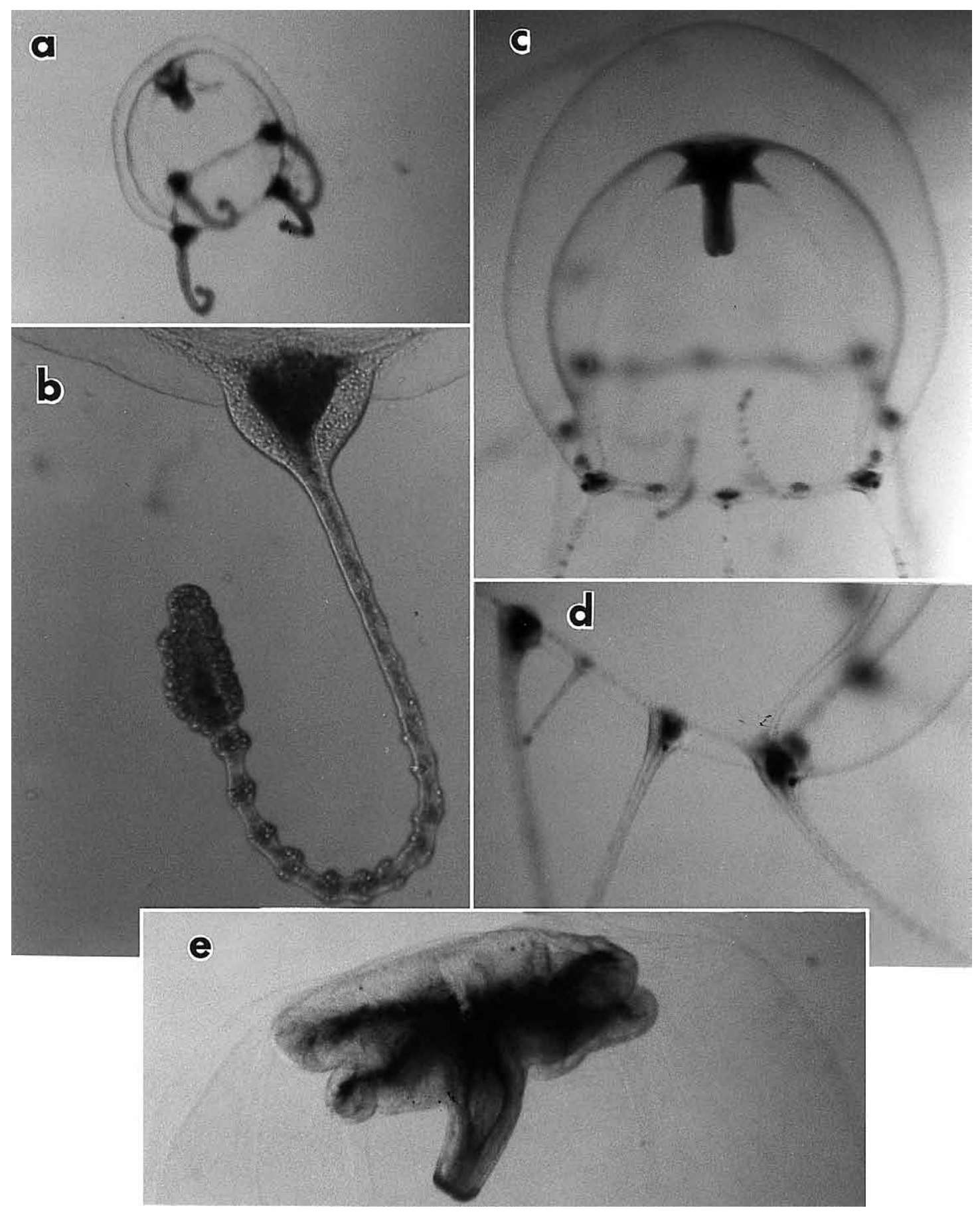

FIG. 4. - Moerisia sp., growth stages of the medusa. (a) Newly-released medusa, 1.0 mm bell height. (b) Close-up of one tentacle of newlyreleased medusa: note elongate terminal knob and nematocysts arranged in rings. (c) Ten-day old laboratory-reared medusa, 16-tentacle stage; bell height $2.0 \mathrm{~mm}$. (d) Margin and tentacle bulbs on 24-day old laboratory-reared medusa, $4.0 \mathrm{~mm}$ in bell height: note the prominent ocelli. (e) Gonad of (d) appears to continue from radial canals onto the stomach wall.

been found in Chesapeake Bay in the eastern USA and designated M. lyonsi Boulenger, 1908 by Calder and Burrell (1967), morphological differences in both the medusa and polyp phases of the life cycle (discussed below) prevent us from assigning the Suisun Slough Moerisia to that species.

\section{Morphology and Growth Stages of the Medusa} (Figs. 4, 5)

Various size classes, including newly-released medusae, were collected from the plankton. Newlyreleased medusae (Fig. 4a) were about $0.8 \mathrm{~mm}$ in 
bell height, as wide as wide, with four tentacles, each with a prominent tentacle bulb with red ocellus at its base, and with a terminal nematocyst knob. The nematocysts on the tentacles were arranged in rings (Fig. 4b). The mesoglea of the bell was uniformly thin, and the exumbrella was sprinkled with nematocysts. There were four radial canals. The simple tube-shaped manubrium extended about $1 / 4$ into the subumbrellar cavity. There were no traces of gonads. In some newly-released medusae the beginnings of the tentacle bulbs in the next cycle of four tentacles were apparent. Statocysts were absent.

In those medusae raised in the laboratory from cultured polyps, age could be correlated with the size, tentacle number, and extent of gonad development in medusae from the plankton. Laboratoryreared medusae about 10 days old ranged in size from 1.5-2.5 mm bell height and diameter (Fig. 4c). The mesoglea in medusae of this size had gradually thickened, especially at the apex of the bell. Eight to sixteen tentacles and tentacle bulbs were evenly spaced around the bell margin, each bulb possessing a red ocellus. Tentacles arose from oval tentacle bulbs, and the upper margins of the bulbs were adnate to the exumbrella. Gonad development was just beginning on that part of the radial canals adjacent to the stomach. Laboratory-reared medusae of 24 days old (Fig. 4d,e) were about the same size as most of the largest found in the field, about 3.5-4.2 $\mathrm{mm}$ bell height, with 19-31 tentacles. Gonads extended only about $1 / 3$ of the way down the radial canals in laboratory-reared medusae (Fig. 5a), but had the same general cruciform shape as those from the plankton (Fig. 5c and below).

The largest field-collected medusa was $8.1 \mathrm{~mm}$ in bell diameter and sexually mature, but most mature medusae ranged from $4.0-4.5 \mathrm{~mm}$ in bell height and diameter. The bell was dome-shaped and the mesoglea thick, especially at the bell apex (Fig. $5 c)$. Gonads were cruciform in general appearance, and gonadal tissue extended from the base of the stomach along each of the four radial canals from $1 / 2$ to $2 / 3$ of the way to the ring canal (Fig. 5 b,c). In some individuals, the distal ends of the gonads were somewhat pendant. The manubrium was simple and tubular, and extended only about $1 / 4$ of the length of the subumbrellar space. The gonads appeared to extend continuously onto the upper part of the manubrial wall. The number of tentacles in mature medusae varied from 25 to a maximum of 32 . There was a prominent red ocellus at the base of each tentacle bulb. The arrangement of nematocysts on the
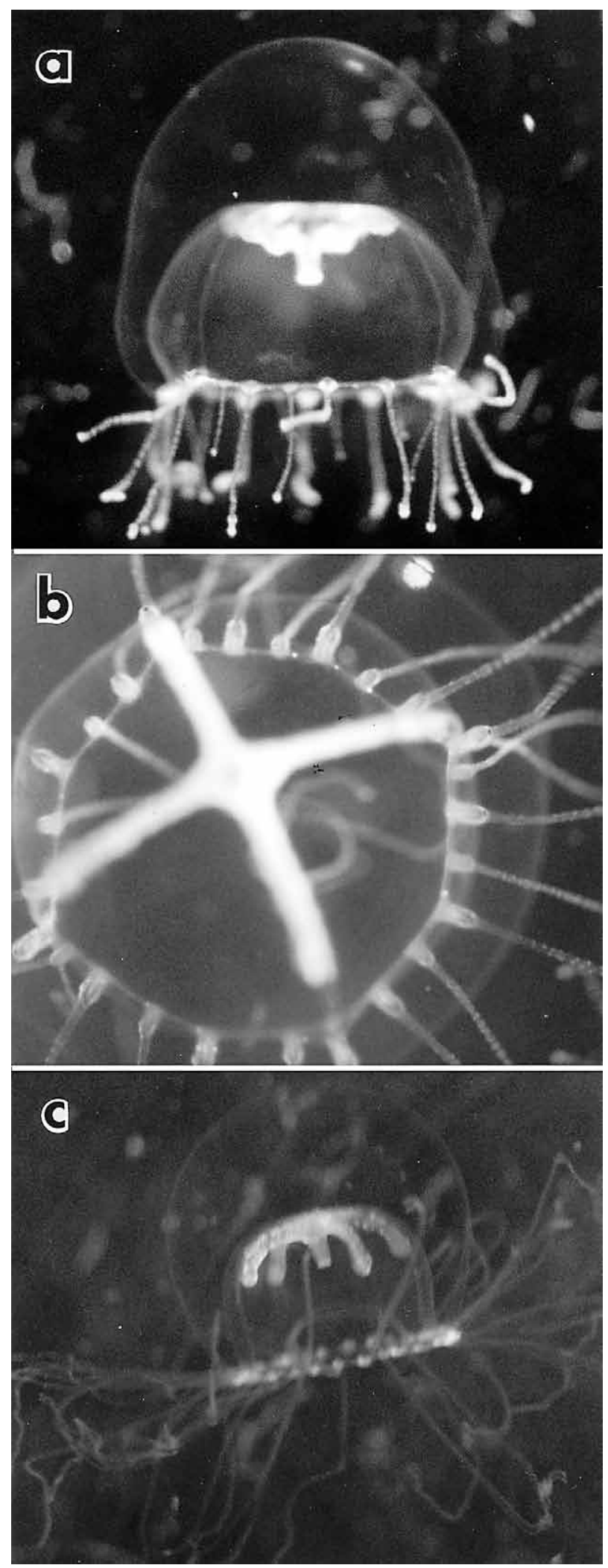

FIG. 5. - Moerisia sp., mature medusa. (a) Laboratory-reared medusa, lateral view, $4.0 \mathrm{~mm}$ bell height, 24 days old. (b) Field-collected medusa, aboral view, $4.5 \mathrm{~mm}$ bell height: note cruciformshaped gonads. (c) Field-collected medusa, lateral view, $5.0 \mathrm{~mm}$ bell height. 


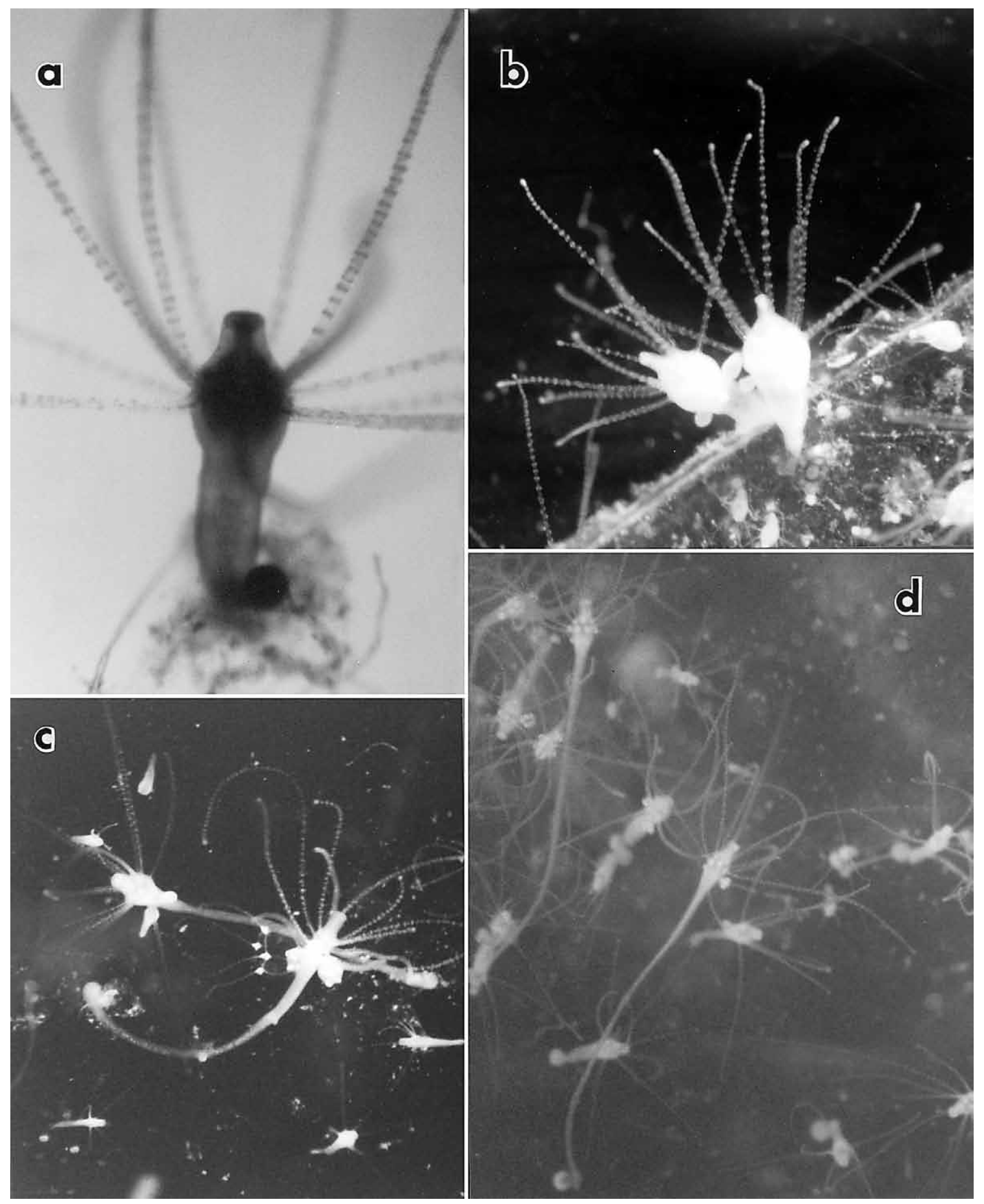

FIG. 6. - Moerisia sp. polyps, all reared in the laboratory. (a) Young polyp, $1 \mathrm{~mm}$ high: note nematocyst rings on tentacles and pedal disc at the base. (b) Two contracted polyps, $2 \mathrm{~mm}$ in height, both with planular buds: note slightly capitate nature of the tentacles. (c) Two expanded polyps, the larger hydranth bears a medusa, about $1 \mathrm{~mm}$ in diameter, ready for release; the hydranth at the left bears a planular body ready for release. (d) Group of polyps in various states of expansion; the longest polyps are more than $10 \mathrm{~mm}$ in length.

tentacles was usually in evenly-spaced rings, although occasionally nematocyst clasps (incomplete rings) were present. Translucent eggs were visible in the gonads of mature females, whereas mature male gonads appeared an opaque white color. The gonads and tentacle bulbs were opaque, and the mesoglea was transparent, rendering the medusae virtually invisible in turbid water. The cruciform opaque gonad, transparent mesoglea, and oval tentacle bulbs equipped with ocelli, coupled with a low salinity environment, allow adult Moerisia medusae to be easily recognized. 


\section{Behavior}

Both laboratory-reared and field-collected Moerisia sp. medusae were relatively weak swimmers; medusae of all sizes were phototactic and pulsed towards a fixed light source in the laboratory. The medusae were occasionally observed positioned in mid-water in their culture containers, tentacles extended, presumably in a feeding posture, although in unaerated cultures Moerisia sp. medusae spent most of the time on the container bottom with tentacles extended. The medusae were very efficient predators, and any excess Artemia nauplii fed to them were quickly killed, but not necessarily consumed. Dead, uneaten nauplii fell to the bottom of the rearing containers and were removed immediately to prevent fouling of the cultures.

\section{The polyp (Fig. 6)}

Mature Moerisia sp. medusae from the field spawned readily in finger bowls. Eggs were opaque, about $100 \mu \mathrm{m}$ in diameter, and sank to the bottom. Development into planulae occurred within 24-48 hours. Primary polyps were noted attached to the bottoms and sides of the bowls within 3-4 days after spawning. The primary polyps were minute, with a body diameter of about $0.1 \mathrm{~mm}$. Three or four evenly-spaced tentacles surrounded the mouths of the polyps. The tentacles were very thin and highly extensile, and could stretch to a maximum of about $1 \mathrm{~mm}$ in length. The ends of each tentacle were slightly capitate. The primary polyps could capture and consume Artemia nauplii much larger than themselves. Newly hatched nauplii were occasionally eaten whole, but more often the highly expandable mouth of the polyp would engulf and digest a single naupliar appendage. As the polyps grew, they quickly began to consume entire nauplii of any size.

Polyps grew quickly, and within 2-3 weeks had attained heights of about $1 \mathrm{~mm}$ (Fig. 6a). Nematocysts on the polyp tentacles were arranged in rings. The mouth, rimmed with nematocysts, was mounted on a conical hypostome. A pedal disc, or discshaped piece of tissue covered with perisarc, developed at the base of the hydranth at this early stage. The formation and release of planular bodies or buds, described by others who have observed Moerisia-type polyps (e.g. Uchida and Nagao, 1959), also began at this stage; the buds developed beneath the tentacles on the body of the hydranth (Fig. 6b). Within 1-2 weeks after release and settle- ment of the buds, they in turn developed into new polyps and produced their own buds. In this manner, dense mats of individual polyps developed in culture over 1-2 months.

In mature polyps, the medusa buds were formed among, or slightly below, the tentacles (Fig. 6c). While several (2-4) medusa buds were usually present on a mature polyp, development into liberated medusae occurred serially - only one medusa per polyp was released at any given time. Among the thousands of polyps observed in culture, virtually all were solitary, unlike the colonies of $M$. lyonsi polyps described by Purcell et al. (1999). Branching of polyps, or formation of double-headed polyps, was noted once, in an older, neglected culture (3-6 months old). Perisarc was never noted on any part of the hydranth, although older polyps developed several pedal discs covered by perisarc. The polyps could readily change shape, and the largest mature polyps were capable of great extension of the lower part of the hydranth, such that the polyp body appeared mounted on a thin thread. Such polyps were capable of extension up to $4 \mathrm{~cm}$ or more in length. The number of tentacles varied depending on the age of the polyp, with the youngest polyps having 3-4 tentacles and mature polyps with medusa buds having about 10 tentacles (Fig. 6d).

\section{Cnidom}

Nematocysts of Moerisia sp. polyps and medusae (Fig. 7c-f) was similar in complement and dimensions to those reported by Calder (1971) for Moerisia lyonsi from the Chesapeake Bay and by Uchida and Nagao (1959) for Moerisia (=Ostroumovia) horii from Japan. The polyp had both stenoteles (9-11 x 11-14 $\mu \mathrm{m}$ ) and desmonemes (3-4 $\times 7-8 \mu \mathrm{m})$ on the tentacles, and stenoteles (7-12 $\times 9-16 \mu \mathrm{m})$ only on the lip of the mouth. The mature medusa had both stenoteles (7-10 x 8-12 $\mu \mathrm{m})$ and desmonemes $(3-4 \times 7 \mu \mathrm{m})$ on the tentacles. The exumbrella of the newly-released medusa had small unidentified nematocysts $(2-3 \times 6-7 \mu \mathrm{m})$ that were never seen exploded, but were similar to the basitrich capsules figured by Uchida and Nagao (1959, p. 277) for Moerisia horii.

\section{Systematics}

The taxonomic status of the Moerisia found at Suisun City remains unresolved. It seems most similar to $M$. lyonsi, which however usually has only 4 


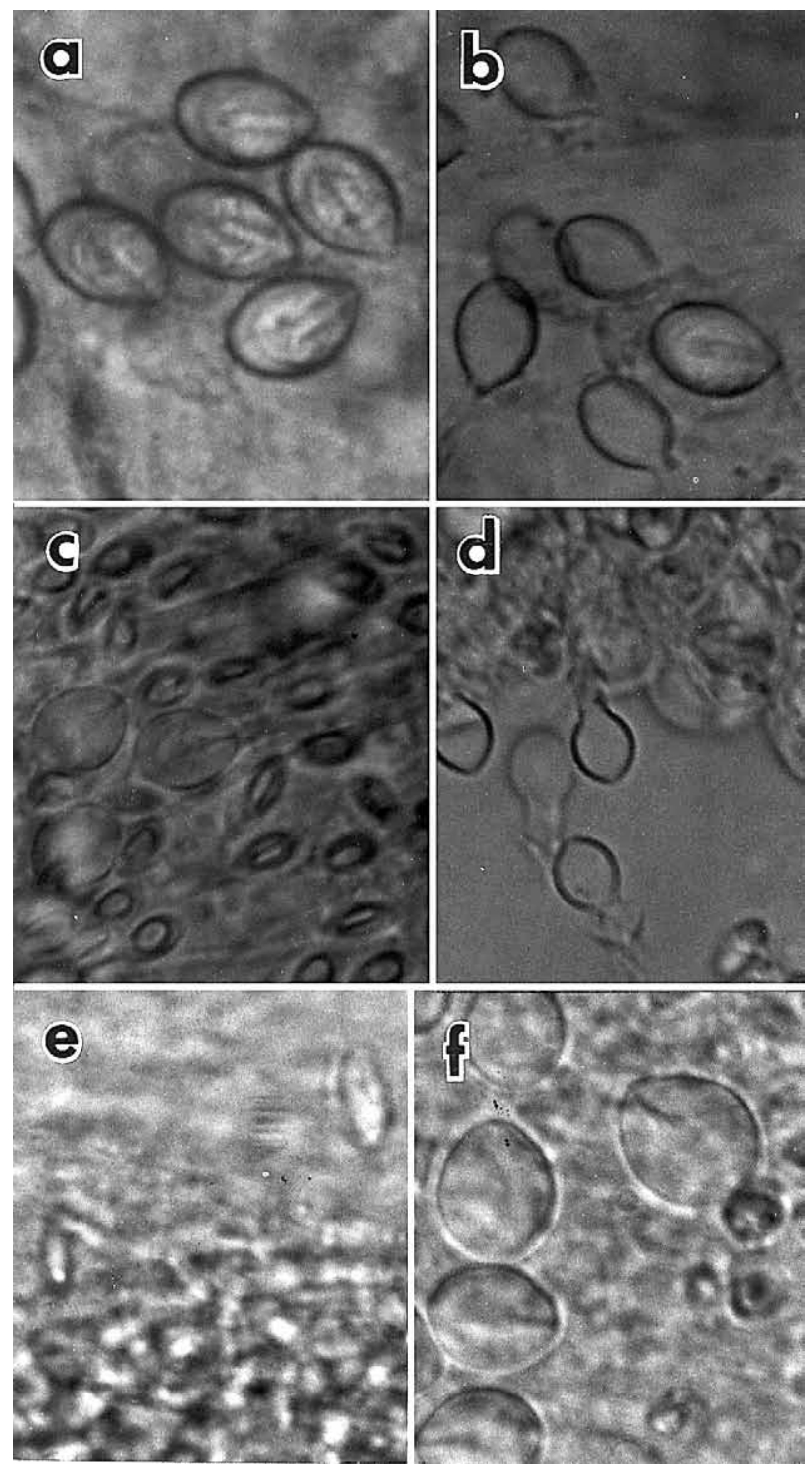

FIG. 7. - Nematocysts of Maeotias marginata and Moerisia sp.; see text for sizes. (a) Microbasic euryteles from tentacles of M. marginata adult medusa, unexploded. (b) Microbasic euryteles from tentacles of $M$. marginata adult medusa, exploded. (c) Larger stenoteles and more numerous smaller desmonemes from Moerisia sp. medusa, $1.3 \mathrm{~mm}$ bell height. (d) Exploded stenoteles from Moerisia sp. medusa, $1.3 \mathrm{~mm}$ bell height. (e). Basitrichs (?) from exumbrella of newly released medusa of Moerisia sp., unexploded. (f) Stenoteles and desmonemes from Moerisia sp. polyp tentacle, unexploded.

tentacles as an adult (Boulenger, 1908), with occasionally up to 22 (Kramp, 1961). We suggest, but have little evidence for, a scenario which would synonymize the genera Odessia and Ostroumovia with Moerisia, as proposed by Naumov (1960). Naumov lumped all three genera into two Moerisia species: M. maeotica and M. pallasi, found respectively in the Black and Caspian Seas (his monograph did not include $M$. lyonsi, which had not been collected in the USSR). Peterson (1990) retains both Moerisia and Odessia as separate genera. We suspect that the first Moerisia described, M. lyonsi from Lake Moeris in Egypt, is not unique and different from all other Moerisias, because it seems very likely to be an introduction into the Nile basin. All M. lyonsi medusae described by Boulenger (1908) were males, indicating (as described for Maeotias marginata in the Petaluma River by Mills and Sommer, 1995) an entire population that could have descended from a single introduced male polyp. We suspect that other Moerisia medusae described from various parts of the globe, including $M$. gangenica in India and M. lacustris from fresh water in Trinidad, might also have been introduced, and that ultimately the family Moerisiidae may prove to contain only one or two species in the genus Moerisia with considerable morphological plasticity. Resolution of the taxonomic status of this genus will require collections in the Black and Caspian Seas, laboratory rearing studies, and ultimately genetic taxonomic work from specimens collected world-wide.

\section{DISCUSSION}

The San Francisco Estuary has the greatest number of recorded marine and aquatic introductions in North America, if not the world (Cohen and Carlton, 1995). There were probably no coelenterates (with the possible exception of Hydra) native to the lowsalinity upper San Francisco Estuary prior to the Gold Rush in the mid-nineteenth century. The introduction of these two non-native hydrozoans probably represents the accommodation of a previously empty ecological niche by these secondary plankton consumers. Their potential and real effects on other native plankton and fish species, and the entire planktonic community structure of the upper Estuary, remains to be investigated.

There are few data on food preferences for either of these species, but both appear to specialize on crustaceans. Mills and Sommer (1995) reported that 70 field-collected adult $M$. marginata medusae had fed primarily on barnacle and copepod nauplii, planktonic and benthic copepods, and crab zoea larvae. Purcell et al. (1999) reported that Chesapeake Bay-resident Moerisia lyonsi in the laboratory demonstrated a clear preference for copepods and their nauplii.

Neither of these medusae is known to have predators, and both have the potential to invade all low-salinity San Francisco Estuary environments, 
the sessile polyps of both species being transportable on the bottoms of boats of all sizes. The source and vehicle for the introduction of both of these species into the Estuary is unknown, but could have been ballast water from Black Sea or Chesapeake Bay ports being discharged into the Bay as described by Carlton (1985), or as part of a ship's fouling fauna. The San Francisco Estuary sees heavy commercial ship traffic from ports throughout East Asia, and a more likely introduction scenario might provide these hydrozoans arriving from an East Asian port into which they had been previously introduced, but not yet reported. Both species have the potential to invade any estuary world-wide with conducive environments, and additional reports and sightings elsewhere are to be expected.

Our lack of knowledge of the biology of both of these species precludes detailed predictions based on habitat preference and dispersal. Calder and Burrell $(1967,1969)$ reported Moerisia lyonsi in the Chesapeake Bay in salinities of 2.3 psu and M. marginata (as $M$. inexpectata) in salinities as low as 1.2 psu. Purcell et al. (1999) found Moerisia lyonsi in salinities from 0-5 psu in tributaries to the Chesapeake Bay. Laboratory studies on salinity and temperature preferences for all stages of the life cycles of both species are needed to fully assess their invasive capabilities.

The potential for severe ecological disturbance similar to that which befell commercial fish populations in the Black Sea following the introduction of the ctenophore Mnemopsis leidyi A. Agassiz, 1865 (Harbison and Volovik, 1994), could also result from hydrozoan introductions into estuarine habitats with depauperate faunas and vulnerable populations of native species. These nonindigenous hydrozoan species, including also Blackfordia virginica (see Mills and Rees, 2000), should be monitored as part of a Bay-wide effort to track both native and introduced coelenterate species. Monitoring results can be used to assess effects of introduced species on valuable fisheries resources, and to assess future efforts to limit further aquatic introductions.

\section{ACKNOWLEDGEMENTS}

We are indebted to Jere Lipps and the Department of Integrative Biology, UC Berkeley, for use of laboratory space and equipment, and to the Harbormaster and local residents at the Suisun City Marina for allowing us to use the facility and providing us with valuable information. The polyps of Maeotias marginata were obtained in the laboratory during the Fourth Hydrozoan Workshop, held at the Bodega Marine Laboratory of the University of California. Shin Kubota of the Seto Marine Biological Marine Laboratory, who attended the workshop, helped J.T.R. collect M. marginata, and was first to find female medusae during collections in 1998. Thanks to Claudia Mills for her usual excellent editorial suggestions and general assistance. Support was in part provided by a cooperative agreement from CALFED and the US Fish and Wildlife Service (\#114209J018) to California State University Hayward and the Environmental Research Center at Alameda Point, and from the University of California at Berkeley. Ongoing study of San Francisco Estuary medusae was assisted by a grant from the Interagency Ecological Program and the California Department of Water Resources to CSU Hayward and the Environmental Research Center under DWR agreement \#B-81818.

\section{REFERENCES}

Agassiz, L. - 1862. Contributions to the Natural History of the United States of America, volume IV.

Boulenger, C. L. - 1908. On Moerisia lyonsi, a new hydromedusan from Lake Qurun. Quart. J. Microsc. Sci., 52: 357-378.

Calder, D.R. - 1971. Hydroids and hydromedusae of southern Chesapeake Bay. Virginia Inst. Mar. Sci. Special Papers Mar. Sci., 1: xi + 125 pp.

Calder, D.R. and V.G. Burrell. - 1967. Occurrence of Moerisia lyonsi (Limnomedusae, Moerisiidae) in North America. Am. Midl. Nat., 78: 540-541.

Calder, D.R. and V.G. Burrell. - 1969. Brackish water hydromedusa Maeotias inexpectata in North America. Nature, 222: 694-695.

Carlton, J.T. - 1985. Transoceanic and interoceanic dispersal of coastal marine organisms: the biology of ballast water. Oceanogr. Mar. Biol. Ann. Rev., 23: 313-371.

Cohen, A.N. and J.T. Carlton. - 1995. Biological Study: Nonindigenous aquatic species in a United States estuary: A case study of the biological invasions of the San Francisco Bay and Delta. U.S. Fish and Wildlife Service and the National Sea Grant College Program, Connecticut Sea Grant, 246 pp. and 5 unpaginated appendices.

Harbison, G.R. and S.P. Volovik. - 1994. The ctenophore, Mnemiopsis leidyi, in the Black Sea: a holoplanktonic organism transported in the ballast water of ships. In: Proceedings of the National Oceanic and Admospheric Administration Conference and Workshop on Nonindigenous Estuarine and Marine Organisms. pp. 25-36. U.S Government Printing Office, Washington, D.C.

Kramp, P.L. - 1961. Synopsis of the medusae of the world. J. Mar. Biol. Assoc. U.K., 40: 1-469.

Mills, C., J.T. Rees and C. Hand. - 1976. A new species of Aglauropsis (Hydrozoa: Limnomedusae) from the Northeastern Pacific, with notes on Aglauropsis conantii and Eperetmus typus. Wasmann J. Biol., 34: 23-42.

Mills, C.E. and F. Sommer. - 1995. Invertebrate introductions in marine habitats: two species of hydromedusae (Cnidaria) native to the Black Sea, Maeotias inexspectata and Blackfordia virginica, invade San Francisco Bay. Mar. Biol., 122: 279-288.

Mills, C.E. and J.T. Rees. - 2000. New observations and corrections concerning the trio of invasive hydromedusae Maeotias marginata (=M. inexpectata), Blackfordia virginica, and Moerisia 
sp. in the San Francisco Estuary. Sci. Mar., 64(Supl. 1): 151-155 Naumov, D.V. - 1960. Hydroids and hydromedusae of the USSR. Izd. Akad. Nauk USSR, 70: 1-660. (Translated from Russian by Israel Program for Scientific Translations, Jerusalem, 1969).

Petersen, K.W. - 1990. Evolution and taxonomy in capitate hydroids and medusae. Zool. J. Linnean Soc., 100: 101-231.

Purcell, J.E., U. Båmstedt and A. Båmstedt. - 1999. Prey, feeding rates, and asexual reproduction rates of the introduced oligohaline hydrozoan Moerisia lyonsi. Mar. Biol., 134: 317-325.
Rees, J.T. - 1979. Laboratory and field studies on Eutonina indicans (Coelenterata: Hydrozoa), a common Leptomedusa of Bodega Bay, California. Wasmann J. Biol., 36: 201-209.

Russell, F.S. - 1953. The Medusae of the British Isles. Vol. I. Hydromedusae. The University Press, Cambridge, xii +530 pp., 35 pls.

Uchida, T. and Z. Nagao. - 1959. The life-history of a Japanese brackish-water hydroid, Ostroumovia horii. J. Fac. Sci. Hokkaido Univ. Ser. 6, Zool., 14: 265-281. 